\title{
Ryegrass management in lowland areas on the establishment and development of soybean in succession
}

\author{
Lucas Lopes Coelho ${ }^{1} \oplus$, Enio Marchesan ${ }^{1} \oplus$, Maurício Limberger de Oliveira ${ }^{1} \oplus$, Augusto Dubou Serafin ${ }^{1}{ }^{\circ}$,

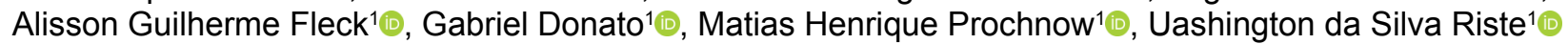

\footnotetext{
1 Universidade Federal de Santa Maria, Santa Maria, RS, Brasil. E-mail: lucas_I_c@hotmail.com; eniomarchesan@gmail.com; mauriciodeoliveira8@hotmail.com;
} \\ augustodserafin@hotmail.com; alissongfleck@gmail.com; gabriel.donato@hotmail.com; prochnow.matias@gmail.com; uashington03@gmail.com
}

ABSTRACT: The objective of this work was to determine the effect of desiccation and haymaking periods in the off-season on the quality of hay produced and nutrient accumulation, as well as to quantify the effects of remaining dry mass on the establishment and development of soybean in lowland areas. The experiment was conducted in the field in the 2015/16 and 2016/17 growing season in the lowland area of the Federal University of Santa Maria, Rio Grande do Sul, Brazil. Two treatments of ryegrass management (hay and desiccation) in five periods and one fallow period were tested. The study implemented an experimental randomized block design. The following variables were measured in the off-season: ryegrass dry shoot mass, hay quality parameters, moisture and nutrient content in the soil. In addition, the initial population of plants, dry shoot mass, nodule dry mass and grain yield were determined in the soybean. The cultivation of ryegrass hay in lowland area is a viable alternative. However, it reduces the potassium content in the soil if it is not replaced by fertilization. The use of ryegrass, regardless of the period of haymaking or desiccation, increases the water retention in the soil, which promotes straw wrapping and/or mirroring of the soil in a year of elevated precipitation, with a consequent reduction of the initial plant population and soybean grain yield when compared to the fallow system.

Key words: hay; irrigated rice; Lollium multiflorum; off-season

\section{Manejo de azevém em terras baixas sobre o estabelecimento e desenvolvimento} da soja em sucessão

RESUMO: O objetivo do trabalho foi determinar o efeito de épocas de dessecação e fenação do azevém na entressafra sobre a qualidade do feno produzido e o acúmulo de nutrientes no solo, bem como quantificar os efeitos da massa seca remanescente sobre o estabelecimento e desenvolvimento da soja em terras baixas. Foi conduzido um experimento durante as safras agrícolas 2015/16 e 2016/17, na área de terras baixas da Universidade Federal de Santa Maria, Rio Grande do Sul, Brazil. Foram testados dois manejos do azevém (fenação e dessecação) em cinco épocas, mais um tratamento pousio. $O$ delineamento experimental foi o de blocos ao acaso. Na entressafra, foram mensuradas a massa seca da parte aérea (MSPA) do azevém, parâmetros de qualidade do feno e teor de umidade e nutrientes no solo. Na soja, determinou-se a população inicial de plantas, a MSPA e de nódulos e a produtividade de grãos. A produção de feno de azevém em terras baixas é uma alternativa viável. Entretanto, reduz o teor de potássio no solo caso o mesmo não seja reposto via adubação. A utilização do azevém, independentemente da época de fenação ou dessecação, aumenta a retenção de água no solo, a qual em ano de elevada precipitação propicia o envelopamento da palha e/ou espelhamento do solo, com a consequente redução da população inicial de plantas e da produtividade de grãos da soja, quando comparado ao sistema com pousio.

Palavras-chave: feno; arroz irrigado; Lollium multiflorum; entressafra 


\section{Introduction}

The use of lowland areas in southern Brazil was based on the irrigated rice monoculture for many years. However, the high pressure of resistant weeds established the need to insert other crops in this productive environment. Nevertheless, there are countless factors which restrict the use of a diversified rotation system and/or succession of cultures in these areas. The main limiting factors can be the physical and chemical characteristics of these soils, which have high compaction (Giacomeli et al., 2016), deficient drainage (Fin et al., 2018), low organic matter content and high acidity (Reis et al., 2016).

Soybean was one of the first crops to be introduced into the rotation system with irrigated rice. The crop initially entered these areas in order to mitigate problems caused by crops being infested with weeds which are difficult to control, with an emphasis on weed rice. Advancing technology in legume production in these areas subsequently made it possible for soybean to consolidate itself as an alternative not only for management, but also for income in this productive environment.

The insertion of this new crop brought with it the need to review management practices adopted during the offseason. This period has historically been dedicated to a spatial reorganization of areas through conventional soil preparation, keeping them with only spontaneous vegetation afterwards until the next cultivation. From the point of view of soil conservation, this system has been reported for its greater susceptibility to erosive processes and the loss of nutrients (Singh \& Sidhu, 2014).

The inclusion of cover crops appears as an alternative to the off-season, enabling physical protection of the soil, nutrient cycling and increasing income from the property. For Silva et al. (2007), the ideal species for this purpose are those which produce high amounts of dry matter, are resistant to pests and diseases, and at the same time have low demands on soil fertility. Thus, ryegrass can be highlighted among the best adapted species, as it has a high potential for mass production in the lowland rotation system. In addition, the crop has other attractive points such as ease of implantation and a diversified use such as animal grazing, hay production and the soil cover itself.

On the other hand, the amount of straw at the time of sowing is one of the major questions about the use of cover crops in this environment. When straw is in large quantities on the soil surface, it can alter the action of the elements which make up the evapotranspirative demand of the atmosphere (Anjos et al., 2017), increasing moisture retention and consequently reducing the optimal water interval for mechanized operations. As a result, there may be problems with implanting soybeans at the best time, as well as causing difficulties in seed germination due to seed-soil contact (Wells et al., 2013).

Managements which reduce the amount of straw at the time of sowing are essential to enable its use in these areas.
One of the alternatives refers to the desiccation time of the plants, since extending the residue residence time on the soil increases its decomposition (Ferreira et al., 2015). Allied to this, the degradation occurs more intensely when the plant is managed younger due to the greater leaf:stem ratio of the material (Redin et al., 2014).

The use of physical methods is another alternative, in which the removal of straw for making hay can be highlighted. According to a study by Ferreira et al. (2015), ryegrass has high potential for hay production in lowland areas, reaching more than $4.5 \mathrm{t}^{\text {.ha-1 }}{ }^{-1}$, representing an alternative source of income for the producer. Another point to be noted refers to the cutting season of the plants, given that the forage development stage has a marked influence on its nutritional quality.

Thus, this study aimed to determine the effect of ryegrass desiccation and hay seasons in the off-season on the quality of the hay produced and the accumulation of nutrients in the soil, as well as to quantify the effects of the remaining dry mass on the establishment and development of soybeans in lowlands.

\section{Materials and Methods}

The experiment was conducted in the field during the 2015/16 and 2016/17 agricultural seasons in the lowland area of the Federal University of Santa Maria (UFSM), Rio Grande do Sul, Brazil $\left(29^{\circ} 43^{\prime} \mathrm{S} 53^{\circ} 43^{\prime} \mathrm{W}\right)$. The soil of the experimental area is classified as Albaqualf (Soil Survey Staff, 2014) or Planossolo Háplico Eutrófico arênico (Santos et al., 2013). The region's climate is Cfa according to the Koppen classification, which is humid subtropical (Moreno, 1961). The soil in the area had the following physicochemical characteristics in the first harvest; clay $=26$ and $28 \%, \mathrm{OM}=2$ and $1.3 \%, \mathrm{pH}$ in water (1: 1) $=6.1$ and 5.1 ; base saturation $=69.9$ and $40.8 \%$; saturation by $\mathrm{Al}=0$ and 1.5\%; P-Mehlich $=18.6$ and $5.3 \mathrm{mg} . \mathrm{dm}^{-3} ; \mathrm{K}=64$ and $26 \mathrm{mg} \cdot \mathrm{dm}^{-3}$ and CEC pH7 = 13.1 and $16.4 \mathrm{cmolc}^{\mathrm{dm}} \mathrm{dm}^{-3}$ in layers 0-0.1 and 0.1-0.2 m deep, respectively.

The experiment was conducted in the same experimental units during the two years of study using a randomized block, design in a $5 \times 2$ bifactorial scheme during the off-season, and four replications. Factor $A$ was formed by two ryegrass managements: (A1) hay production and (A2) desiccation. The factor $D$ levels were composed of five seasons of hay and desiccation: (D1) 82 and 73 days before soybean sowing (DBSS), (D2) 70 and 61 DBSS, (D3) 58 and 49 DBSS, (D4) 46 and 37 DBSS and (D5) 34 and 25 DBSS, respectively, for the 2015/16 and $2016 / 17$ seasons. A fallow treatment was also tested without ryegrass in the off-season, and the experiment was treated as a single factorial with 11 treatments for the variables analyzed in the soil and in the soybean crop. The experimental units had a floor area of $30 \mathrm{~m}^{2}$. For the hay treatments, the plants were cut with a motorized brushcutter at an average height of $0.1 \mathrm{~m}$. In the treatments with desiccation, glyphosate $(1440 \mathrm{~g}$ a.i.ha-1) was applied with a costal machine with fan-type tips and a spray volume of $100 \mathrm{~L} \mathrm{ha}^{-1}$. 
The installation area of the experiment was systematized. The ryegrass sowing was performed by direct seeding in the amount $35 \mathrm{~kg} \mathrm{ha}^{-1}$. The sowing in the first harvest took place on $05 / 23 / 2015$ in a previously prepared area and then the second crop shortly after the soybean harvest on 04/21/2016. The fertilization consisted of three applications of nitrogen $(\mathrm{N})$ (30 kg ha-1 each) in cover at 30, 60 and 90 days after planting the crop. Soybean sowing took place on 7/12/2015 (2015/16 crop) and 11/21/2016 (2016/17 crop). The BMX Valente cultivar was used in the first year, and BMX Icon in the second. The sowing density was 32 seeds $\mathrm{m}^{-2}$. The basic fertilization consisted of $21 \mathrm{~kg} \mathrm{ha}^{-1}$ of $\mathrm{N}, 86 \mathrm{~kg} \mathrm{ha}^{-1}$ of $\mathrm{P}_{2} \mathrm{O}_{5}$ and $86 \mathrm{~kg} \mathrm{ha}^{-1}$ of $\mathrm{K}_{2} \mathrm{O}$ in the sowing line, and an additional $30 \mathrm{~kg} \mathrm{ha}^{-1}$ of $\mathrm{K}_{2} \mathrm{O}$ in the V6 phenological stage (Fehr \& Caviness, 1977).

The dry mass of the ryegrass was determined by collecting two samples of $0.25 \mathrm{~m}^{2}$ per experimental unit at the time of each management as well as at sowing in order to quantify the remaining dry mass. The plants for the desiccation treatments were cut close to the ground, while those for hay production were cut at an average height of $0.1 \mathrm{~m}$, thus allowing the plants to regrow. The samples were dried in a forced ventilation oven at 65 으 until they reached constant mass. After making the hay, samples were collected to quantify the qualitative parameters of the forage mass at the Laboratory of Bromatology and Nutrition of Ruminants at UFSM. The acid detergent fiber (ADF) and neutral detergent fiber (NDF) contents were subsequently determined according to the sequential methodology of Van-Soest et al. (1991). The crude protein content was obtained through Kjeldahl distillation. Digestibility was determined according to the methodology of Tilley \& Terry (1963).

Soil samples were collected in the 0-0.1 m layer in each experimental unit one day before soybean sowing in the 2016/17 harvest to quantify phosphorus and potassium contents. The samples were sent to the Soil Analysis Laboratory at UFSM. Volumetric humidity was also determined at this time, with sampling performed at depths of 0-0.05, 0.05-0.1 and 0.1-0.2 m.

For the soybean crop, the variables initial plant population (IPP), height, shoot dry mass (SDM), the SPAD index, nodule dry mass (NDM) and grain yield were determined. The IPP was measured by counting the number of plants established in an area of $4 \mathrm{~m}^{2}$ in the second and third row of sowing. Next, a soil monolith of $0.50 \times 0.40 \times 0.20 \mathrm{~m}$ (length, width and depth) was collected containing five plants per experimental unit at the V6 phenological stage in the 2015/16 crop and V7 in 2016/17. Afterwards, the root system was washed under running water to separate the soil. The nodules were separated from the roots, being taken together with the shoots of the plants to a forced ventilation oven at $65^{\circ} \mathrm{C}$. The SPAD index was evaluated with a SPAD 502 DL Meter chlorophyllometer. The measurement was performed on the third trefoil completely expanded from the apex to the base of 10 plants per experimental unit. Grain productivity was determined by manual harvesting from an area of $7.5 \mathrm{~m}^{2}$.
The obtained data were then subjected to the mathematical model assumptions test. The analysis of variance was performed using the F-test. The means of the quantitative factor were subjected to polynomial regression analysis for the ryegrass analyzes. The Scott-Knott test was used at a $5 \%$ probability of error when the fallow treatment was compared to the other treatments.

\section{Results and Discussion}

The ryegrass dry mass (DM) in the two analyzed harvests was influenced by the management seasons (Figure 1). Maximum production occurred in treatments with desiccation at 46 DBSS in the 2015/16 crop and 37 DBSS in 2016/17, with a production of 5690 and $10430 \mathrm{~kg} \mathrm{ha}^{-1}$, respectively. When desiccation was carried out at 82 and 73 DBSS, there was a reduction of approximately $50 \%$ in the accumulated DM, and the same tendency is noticed in the treatments with haymaking. The DM values removed from the area via hay production ranged from 2582 to $4538 \mathrm{~kg} \mathrm{ha}^{-1}$ in the first harvest, and from 3595 to $8376 \mathrm{~kg} \mathrm{ha}^{-1}$ in the second, thus representing an important income opportunity during the off-season. In addition, the cutting season affected the plants' regrowth ability (Figures $1 \mathrm{~B}$ and $1 \mathrm{E}$ ), with $\mathrm{DM}$ accumulation being more accentuated the earlier the haymaking occurred.

The remaining DM was also influenced by the treatments, showing significant interaction between the factors (Figures $1 \mathrm{C}$ and 1F). The treatments with desiccation generally provided greater DM at the time of sowing when compared to those with hay, since in the latter the straw was removed from the area. The desiccations closest to soybean sowing at 34 and 25 DBSS resulted in 4637 and $7930 \mathrm{~kg} \mathrm{ha}^{-1}$ of remaining DM, respectively. On the other hand, more desiccated drying considerably reduced the amount of straw at the time of sowing; a fact which can be attributed to the lower plant mass at the management time associated with a longer period of time for the action of soil microorganisms (Ziech et al., 2015). Similar results are described by Ferreira et al. (2015), in which the ryegrass desiccation at 15 DAS of rice provided DM remaining close to $4 \mathrm{t}^{\mathrm{h}} \mathrm{ha}^{-1}$, a value cited as detrimental to the initial plant establishment and grain productivity when compared to desiccations at 45 and 60 DAS and the fallow period.

The nutritional quality of the hay declined with advancement in the crop cycle in the two analyzed crops (Figure 2). However, the reduction was more accentuated in the 2016/17 harvest, since the plants were in a more advanced phenological stage when management started. The crude protein content varied from 7.5 to $16 \%$ in the first harvest, and from 4 to $10.6 \%$ in the second. According to the NRC (1984), a diet with a crude protein content of $12 \%$ is recommended for finishing cattle. Values below $10.5 \%$ may cause a reduction in the digestive capacity of fibers, resulting in less consumption of forage by animals (Cavalcante et al., 2006). It is also worth noting that the CP values in the present 

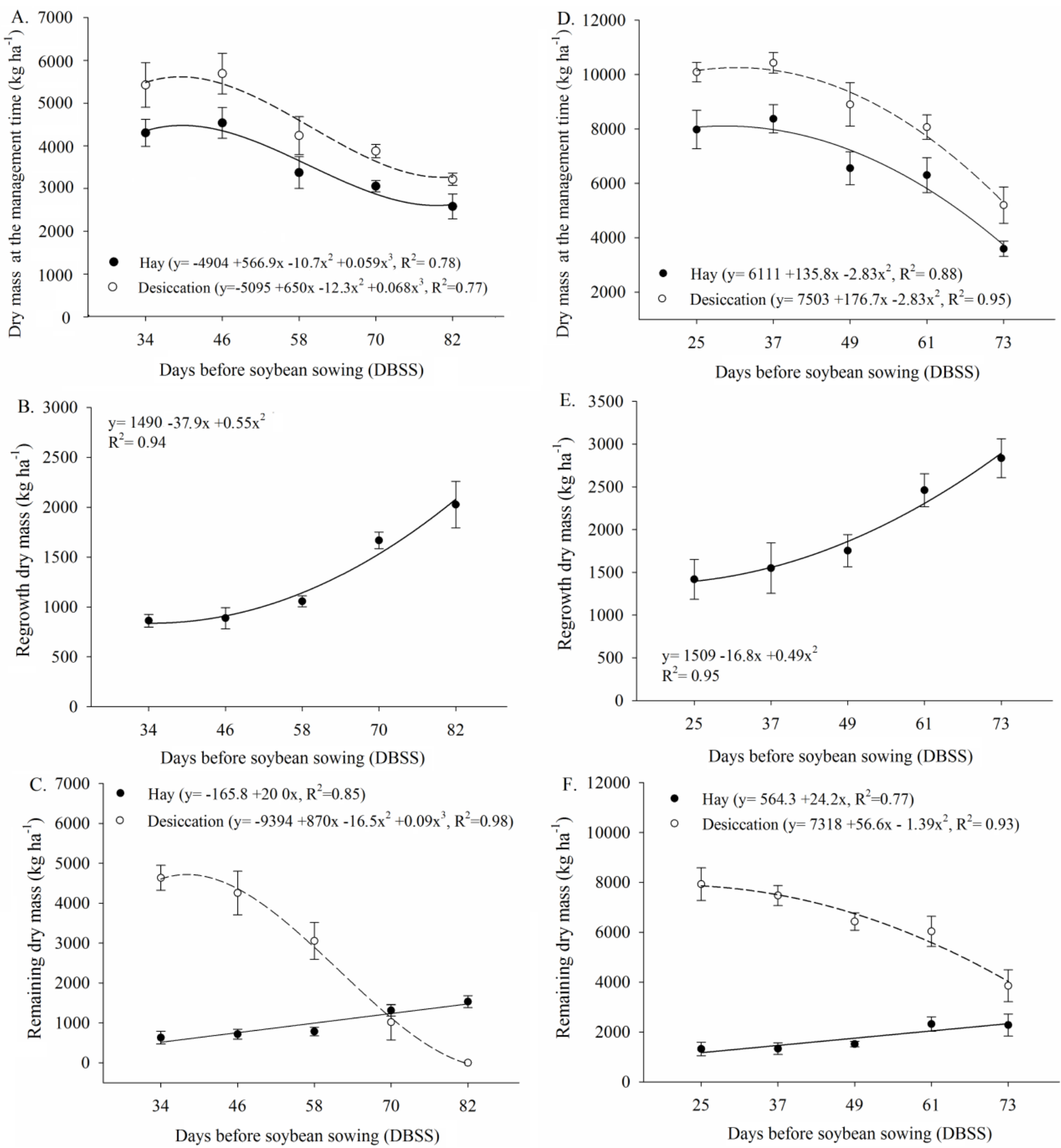

Figure 1. ( $A$ and $D$ ) Dry mass at the management time, ( $B$ and $E$ ) regrowth dry mass, and $(C$ and $F$ ) remaining dry mass of ryegrass, depending on the season of hay and desiccation of the plants aiming at sowing soybean in an area of systematized lowlands. 2015/16 crop (A, B and C) and 2016/17 crop (D, E and F). Santa Maria, RS, Brazil, 2017.

study were found to be above the recommended only in the cuts made at 58, 70 and 82 DBSS in the 2015/16 crop and at 73 DBSS in 2016/17.

The same trend can be observed for the digestibility of organic matter, which reduced by $33 \%$ in the average of the two harvests analyzed between the first and the last haying date, from $77.6 \%$ to $51.7 \%$. Similar results have been reported for the ryegrass culture by Difante et al. (2006), in which the in vitro digestibility levels reached values close to $73 \%$ in the first half of August, then dropping to $41 \%$ at the beginning of grain filling in the second half of October. According to the same authors, digestibility can be defined as the animal's ability to use nutrients from its food, which is an intrinsic characteristic of food, and not of the animal. Thus, Filho et al. (2007) cite that a pasture must present digestibility greater than $75 \%$ to be considered of high nutritional value. 

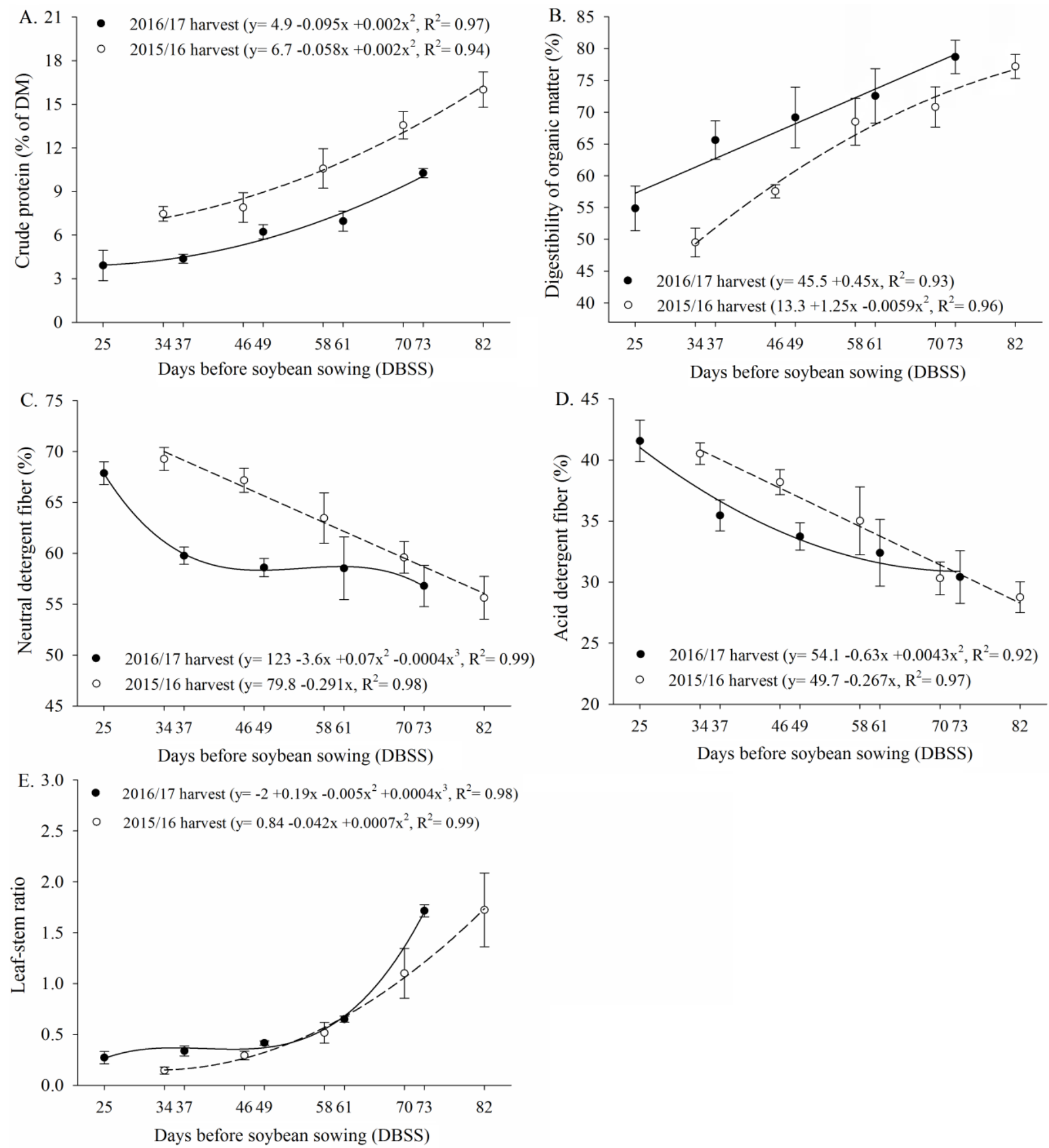

Figure 2. (A) Crude protein, (B) digestibility of organic matter, (C) neutral detergent fiber, (D) acid detergent fiber and (E) leafstem ratio of ryegrass plants depending on the cutting season for hay production in systematized lowland area. Santa Maria, RS, Brazil, 2017.

In contrast, fiber content increased with the proximity of soybean sowing. The ADF had an increase of $30 \%$ between the first and the last cut, while the increase in the NDF was of $20 \%$. These results can be attributed to the change in plant structure, where the leaf:stem ratio went from 1.7 to 0.3 from the first to the last haying season. These results corroborate those of Pellegrine et al. (2010), in which linear increases in the values of NDF and ADF occurred when the participation of leaves was reduced from $50 \%$ to $8 \%$, showing the increase of cellulose and hemicellulose contents in the cellular constitution as the main cause.

Thus, taking into account the guiding parameters of what is considered high quality forage (crude protein and digestibility), it is observed that only the first haying season 
at 82 and 73 DBSS, respectively for the 2015/16 and 2016/17 harvests met these criteria, but with a reduced dry mass production. In this perspective, the haymaking carried out at 70 DBSS in the 2015/16 crop, and at 61 DBSS in the 2016/17 crop, in addition to not presenting large qualitative losses of hay, resulted in an average increase of $1590 \mathrm{~kg} \mathrm{ha}^{-1}$ in the quantity produced, being an alternative to reconcile forage productivity and quality.

In the potassium content analysis in soil 1 DBSS in the 2016/17 harvest (Figure 3A), it is observed that the treatments with hay presented an average value of $37 \%$ lower than with desiccation, and $29 \%$ in relation to fallow. This result can be partly explained by the export of DM from the area, since more than $12 \mathrm{t}$ of DM.ha ${ }^{-1}$ were removed in some hay seasons considering the accumulation of the two harvests, such as the cuts at 34 and 46 DBSS in the first harvest and 25 and 37 DBSS in the second. In this perspective, Silva et al. (2015) mention that forages such as ryegrass present values close to $1.5 \%$ of potassium in their plant composition. If this average value is considered, the accumulated export of the nutrient would
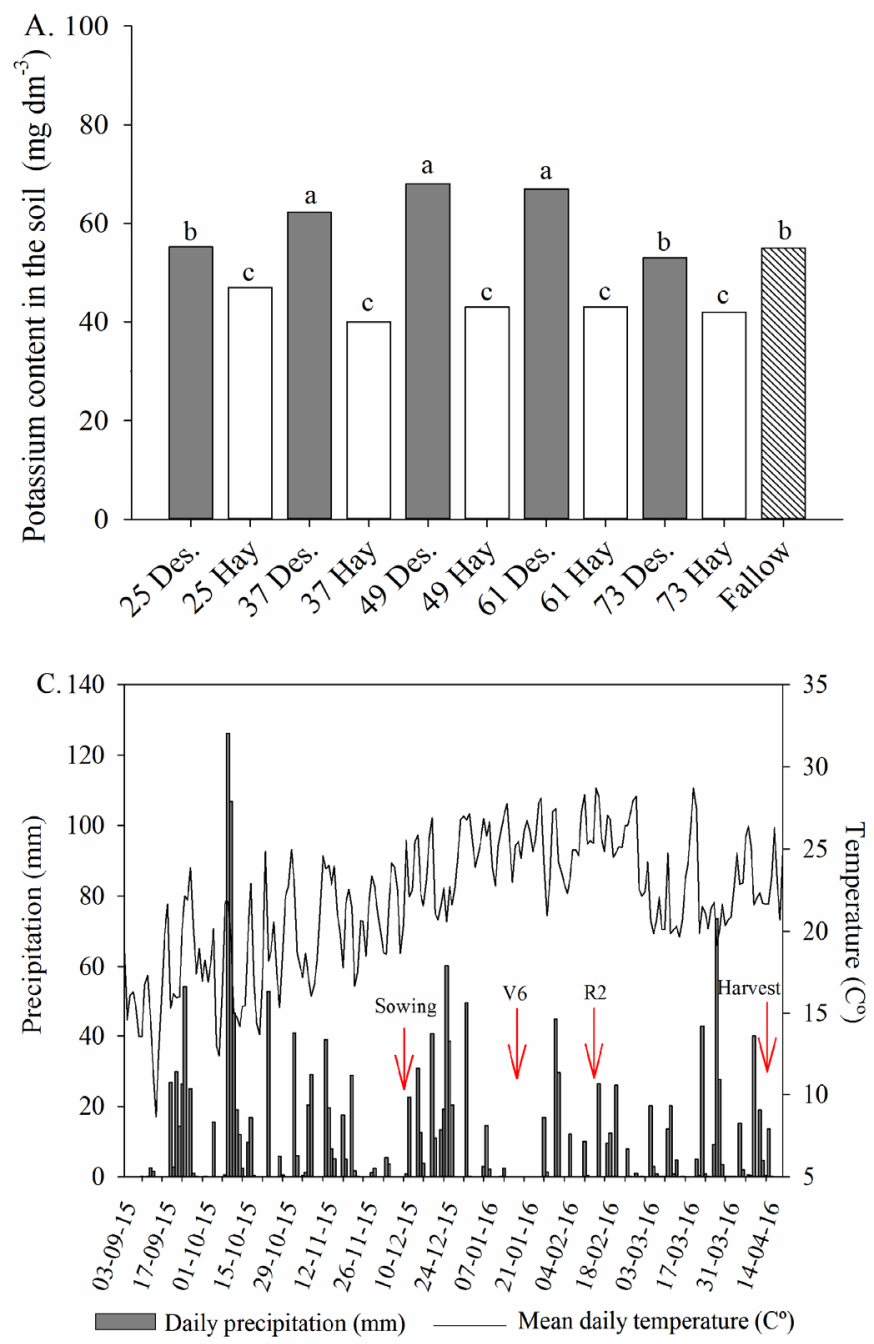

be greater than $180 \mathrm{~kg} \mathrm{ha}^{-1}$ in the referred treatments. The phosphorus content in the soil was not affected (Figure 3B), with an average value of $19.2 \mathrm{mg} . \mathrm{dm}^{-3}$. This result is expected due to the small amount of phosphorus in the constitution of the ryegrass DM, which is situated between $0.2-0.4 \%$ (Assmann et al., 2009; Silva et al., 2015). Thus, the phosphorus export would be close to $35 \mathrm{~kg} \mathrm{ha}^{-1}$ and constituting a value which may have been supplied by the fertilization carried out on the soybean crop. However, in the long run this export may cause a reduction in the levels of this nutrient in the soil, as well as aggravate those of potassium.

Soil moisture 1 DBSS (Table 1 ) in both harvests was strictly related to the remaining DM on the surface. The desiccation treatments resulted in moisture values close to or greater than the field capacity $\left(0.35 \mathrm{~m}^{3} \cdot \mathrm{m}^{-3}\right)$ in the 0-0.05 m layer. It should also be noted that the fallow treatment showed the lowest soil moisture values in both harvests, while it was statistically lower than the others in 2016/17 with a reduction of $41 \%$ when compared to the average of desiccation treatments and $30 \%$ compared to those with hay production. The same trend
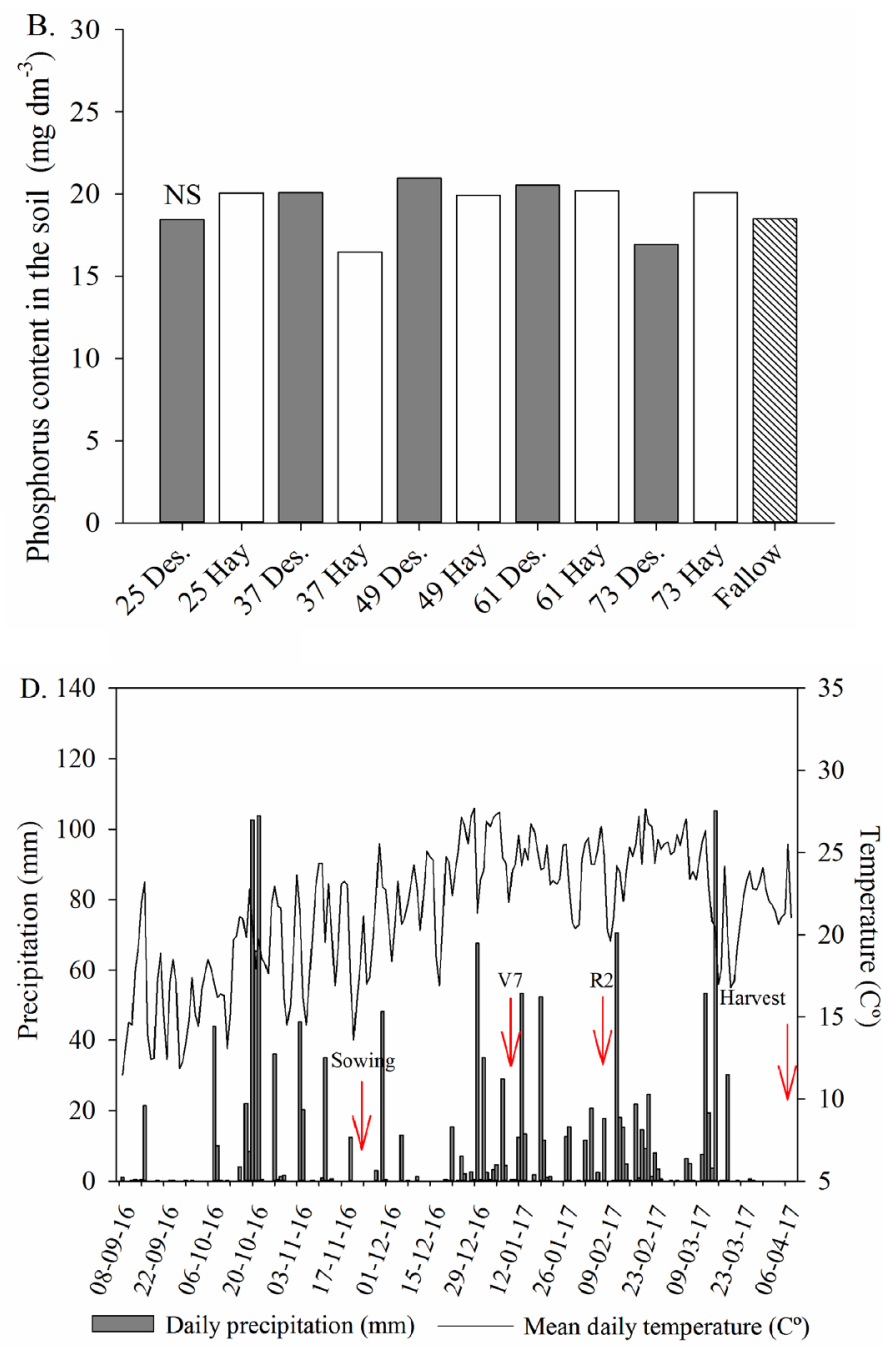

Figure 3. Potassium (A) and phosphorus (B) content in the soil one day before soybean sowing in the $2016 / 17$ harvest as a function of the ryegrass haying and desiccation in a systematic lowland area, and rainfall and mean air temperature in the 2015/16 (C) and 2016/17 (D) agricultural seasons. Santa Maria, RS, Brazil, 2017. Means not followed by the same letter differ from each other by the Scott-Knott test (at 5\% probability), NS-Not significant. 
Table 1. Volumetric soil moisture in the 0-0.05 $\mathrm{m}, 0.05-0.1$ $\mathrm{m}$ and 0.1-0.2 $\mathrm{m}$ depth layers one day before the sowing of soybeans depending on the seasoning and drying of the ryegrass in systematized lowland area. Santa Maria, RS, 2017.

\begin{tabular}{lccc}
\hline \multirow{2}{*}{ Treatments } & $0-0.05$ & $0.05-0.1$ & $0.1-0.2$ \\
\cline { 2 - 4 } & \multicolumn{3}{c}{ 2015/16 Harvest $\left(\mathrm{m}^{3} \mathrm{~m}^{-3}\right)$} \\
\hline Hay 82 DBSS (1) & $0.34 \mathrm{c}^{(2)}$ & $0.33 \mathrm{c}$ & $0.34 \mathrm{~ns}$ \\
\hline Desiccation 82 DBSS & $0.29 \mathrm{~d}$ & $0.33 \mathrm{c}$ & 0.35 \\
Hay 70 DBSS & $0.31 \mathrm{~d}$ & $0.33 \mathrm{c}$ & 0.34 \\
\hline Desiccation 70 DBSS & $0.34 \mathrm{c}$ & $0.34 \mathrm{c}$ & 0.34 \\
Hay 58 DBSS & $0.29 \mathrm{~d}$ & $0.32 \mathrm{~d}$ & 0.34 \\
\hline Desiccation 58 DBSS & $0.37 \mathrm{~b}$ & $0.35 \mathrm{~b}$ & 0.33 \\
\hline Hay 46 DBSS & $0.27 \mathrm{e}$ & $0.31 \mathrm{~d}$ & 0.34 \\
\hline Desiccation 46 DBSS & $0.39 \mathrm{~b}$ & $0.35 \mathrm{~b}$ & 0.34 \\
Hay 34 DBSS & $0.29 \mathrm{e}$ & $0.32 \mathrm{~d}$ & 0.34 \\
\hline Desiccation 34 DBSS & $0.40 \mathrm{a}$ & $0.37 \mathrm{a}$ & 0.35 \\
Fallow (no ryegrass) & $0.26 \mathrm{e}$ & $0.33 \mathrm{c}$ & 0.35 \\
\hline Mean & 0.32 & 0.33 & 0.34 \\
CV (\%) & 5.4 & 3.6 & 6.3 \\
\hline & \multicolumn{2}{c}{$2016 / 17$ Harvest $\left(\mathrm{m}^{3} \mathrm{~m}^{-3}\right)$} \\
\hline Hay 73 DBSS & $0.34 \mathrm{~b}$ & $0.34 \mathrm{~b}$ & $0.35 \mathrm{~ns}$ \\
\hline Desiccation 73 DBSS & $0.39 \mathrm{a}$ & $0.36 \mathrm{a}$ & 0.34 \\
Hay 61 DBSS & $0.32 \mathrm{~b}$ & $0.33 \mathrm{~b}$ & 0.33 \\
\hline Desiccation 61 DBSS & $0.40 \mathrm{a}$ & $0.39 \mathrm{a}$ & 0.35 \\
\hline Hay 49 DBSS & $0.32 \mathrm{~b}$ & $0.32 \mathrm{~b}$ & 0.33 \\
\hline Desiccation 49 DBSS & $0.38 \mathrm{a}$ & $0.37 \mathrm{a}$ & 0.35 \\
Hay 37 DBSS & $0.32 \mathrm{~b}$ & $0.36 \mathrm{a}$ & 0.35 \\
\hline Desiccation 37 DBSS & $0.40 \mathrm{a}$ & $0.39 \mathrm{a}$ & 0.36 \\
\hline Hay 25 DBSS & $0.33 \mathrm{~b}$ & $0.33 \mathrm{~b}$ & 0.34 \\
\hline Desiccation 25 DBSS & $0.37 \mathrm{a}$ & $0.38 \mathrm{a}$ & 0.35 \\
Fallow (no ryegrass) & $0.24 \mathrm{c}$ & $0.33 \mathrm{~b}$ & 0.32 \\
\hline Mean & 0.35 & 0.35 & 0.34 \\
CV (\%) & 7.1 & 6.2 & 6.2 \\
\hline
\end{tabular}

(1) Days before soybean sowing (DBSS), (2) Means not followed by the same letter differ by the Scott-Knott test at $5 \%$ probability of error, ${ }^{\text {ns }}$ Not significant.

is observed in the 0.05-0.1 m layer, but with less magnitude. Similar results are described by Rosin et al. (2014), where the use of 5 and 10 t.ha $^{-1}$ of millet resulted in an increase of 19 and $29 \%$ in soil gravimetric moisture in the 0-0.1 m layer, respectively, when compared to the system without straw. $\mathrm{Li}$ et al. (2018), point out that crop residues on the soil surface reduce the rate of water loss, as they increase shading and reduce the air flow close to the ground, thus constituting factors which ultimately determine the evapotranspirative demand of the atmosphere.

There was no significant difference for IPP in the 2015/16 crop in the parameters evaluated in soybeans, with approximately $50 \%$ of the number of seeds used being established. This low initial stand can partly be attributed to the $67 \mathrm{~mm}$ precipitation which occurred in the six days after sowing (Figure 4A), since the germinative process of seeds is very sensitive to the availability of oxygen in the soil (Grable \& Danielson, 1965). In this sense, Wu et al. (2017) report that a flooding period of 36 hours three days after sowing soybeans is enough to reduce seed germination from $79.2 \%$ to less than $40 \%$. It is therefore noted that the time between sowing and the occurrence of precipitation, as well as its duration and intensity become a critical point in establishing an adequate stand of soybean plants in lowland areas, mainly due to the difficulty of draining these soils. The other variables analyzed in plants such as height, SDM and NDM were not affected by the treatments, nor the grain yield which presented an average of $2978 \mathrm{~kg} \mathrm{ha}^{-1}$.

On the other hand, the management of the off-season in the 2016/17 harvest influenced the results obtained in soybeans. The IPP was higher in the fallow treatment, with 25.6 plants $\mathrm{m}^{-2}$ being established, constituting $33 \%$ more than the average of the other treatments and within the recommended range for the cultivar used. Thus, we can highlight the soil moisture at the time of sowing among the possible explanations for this result. Humidity of $0.24 \mathrm{~m}^{3} \cdot \mathrm{m}^{-3}$ observed in the $0-0.05 \mathrm{~m}$ depth layer in the fallow period provided better crop planting ability, with emphasis on good contact by the seeds with the soil. On the other hand, the high humidity $\left(0.38 \mathrm{~m}^{3} \cdot \mathrm{m}^{-3}\right.$ on average) in the treatments with desiccation made it difficult to cut the straw, causing part of it to be incorporated into the sowing furrow. Despite the smaller remaining DM in the treatments with hay production, there were also problems in closing the sowing grooves due to the side mirroring. As a result, the seed-soil contact was impaired in both ryegrass managements, which made it difficult to absorb the necessary water for the germination process to be completed.

For the variables analyzed in the V7 phenological stage, the fallow enabled a $27 \%$ increase in height and $30 \%$ in the SDM of the plants in relation to the average of the other treatments. This response is partly a reflection of the germination process of the seeds. Thus, germination in treatments with ryegrass management in the off-season (desiccation and haymaking) was triggered in most of the seeds only after the precipitation occurred on the fourth day after sowing, delaying the emergence, and consequently the initial development of the plants. These results corroborate those described by Modolo et al. (2011) for bean crops, where the delay in the emergence of the plants resulted in reflexes in the SDM evaluated at 21 days after sowing. In addition, problems related to planting ability may have been enhanced by the presence of allelopathic compounds, as the germination and initial growth of soybeans may be affected by the release of secondary metabolic compounds during the decomposition of ryegrass plant residues (Nóbrega et al., 2009).

As a result of the planting ability and the initial establishment of plants in the 2016/17 harvest, it was found that the fallow period provided greater productivity of soybeans (3812 kg ha$\left.{ }^{1}\right)$, being $17 \%$ higher than treatments with ryegrass in the offseason. According to Cruz et al. (2016), the establishment of a plant stand which is compatible with the requirements of the cultivar is one of the factors which determines the grain yield of soybeans, since the crop has compensatory capacity due to its limited yield components. Thus, it should be noted that the fallow land in the present study (without ryegrass in the off-season) enabled an increase of 85 thousand plants ha ${ }^{-1}$ in relation to the average of the other treatments, which is a very big difference for there to be satisfactory compensation for the plants. 
Table 2. Initial plant population (IPP), height, shoot dry mass (SDM), nodule dry mass (NDM), SPAD index and grain yield (Prod.) depending on the seasoning and ryegrass desiccation for soybean sowing in a systematic lowland area. Santa Maria, RS, 2017.

\begin{tabular}{|c|c|c|c|c|c|c|}
\hline \multirow[t]{2}{*}{ Treatments } & \multirow[t]{2}{*}{$\begin{array}{c}\text { IPP } \\
\text { (plants } \mathrm{m}^{-2} \text { ) }\end{array}$} & $\begin{array}{c}\text { Height } \\
(\mathrm{cm}) \\
\end{array}$ & $\begin{array}{l}\text { SDMA } \\
\left(\mathrm{g} \mathrm{pl.} .^{-1}\right) \\
\end{array}$ & $\begin{array}{c}\text { NDM } \\
\left(\mathrm{mg} \mathrm{pl.}^{-1}\right) \\
\end{array}$ & $\begin{array}{l}\text { SPAD } \\
\text { Index } \\
\end{array}$ & \multirow{2}{*}{$\begin{array}{c}\text { Prod. } \\
\left(\mathrm{kg} \mathrm{ha}^{-1}\right)\end{array}$} \\
\hline & & \multicolumn{4}{|c|}{ V6 } & \\
\hline \multicolumn{7}{|c|}{ 2015/16 Harvest } \\
\hline Hay 82 DBSS (1) & $17.7^{\mathrm{ns}}$ & $21.1^{\mathrm{ns}}$ & $2.53^{\mathrm{ns}}$ & $147^{\mathrm{ns}}$ & $37.2^{\mathrm{ns}}$ & $2823^{n s}$ \\
\hline $\operatorname{Des}^{(2)} .82$ DBSS & 20.0 & 21.5 & 2.49 & 161 & 35.9 & 3073 \\
\hline Hay 70 DBSS & 16.0 & 20.8 & 2.14 & 154 & 36.8 & 2932 \\
\hline Des. 58 DBSS & 17.7 & 21.0 & 2.09 & 145 & 37.4 & 3145 \\
\hline Hay 46 DBSS & 18.5 & 22.1 & 2.93 & 188 & 37.0 & 2814 \\
\hline Des. 46 DBSS & 17.2 & 20.2 & 2.26 & 161 & 36.5 & 2985 \\
\hline Hay 34 DBSS & 16.2 & 22.1 & 2.18 & 170 & 36.8 & 2957 \\
\hline Des. 34 DBSS & 14.2 & 20.4 & 2.09 & 154 & 36.6 & 2906 \\
\hline Fallow & 19.7 & 20.8 & 2.39 & 152 & 34.8 & 3384 \\
\hline Hay 73 DBSS & $14.5 c^{(3)}$ & $31.2 \mathrm{~b}$ & $3.97 \mathrm{~b}$ & 258 & $40.7^{\mathrm{ns}}$ & $3148 b$ \\
\hline Des. 73 DBSS & $15.5 c$ & $28.9 \mathrm{~b}$ & $4.03 \mathrm{~b}$ & 210 & 41.3 & $3370 \mathrm{~b}$ \\
\hline Hay 61 DBSS & $15.0 \mathrm{c}$ & $28.2 \mathrm{~b}$ & $4.00 \mathrm{~b}$ & 197 & 41.7 & $3188 \mathrm{~b}$ \\
\hline Des. 61 DBSS & $17.0 \mathrm{~b}$ & $28.3 \mathrm{~b}$ & $3.97 \mathrm{~b}$ & 225 & 42.1 & $3381 \mathrm{~b}$ \\
\hline Hay 49 DBSS & $14.5 c$ & $26.8 \mathrm{~b}$ & $4.07 \mathrm{~b}$ & 169 & 41.3 & $3181 b$ \\
\hline Des. 49 DBSS & $18.9 \mathrm{~b}$ & $28.1 b$ & $3.85 b$ & 256 & 40.4 & 3292 b \\
\hline Hay 37 DBSS & $17.5 \mathrm{~b}$ & $26.8 \mathrm{~b}$ & $3.39 \mathrm{~b}$ & 192 & 40.9 & $3118 b$ \\
\hline Des. 37 DBSS & $18.2 \mathrm{~b}$ & $32.3 \mathrm{~b}$ & $3.96 \mathrm{~b}$ & 273 & 41.4 & $3025 \mathrm{~b}$ \\
\hline Hay 25 DBSS & $14.2 \mathrm{C}$ & $25.9 \mathrm{~b}$ & $3.58 \mathrm{~b}$ & 222 & 40.8 & $2868 b$ \\
\hline Des. 25 DBSS & $18.5 \mathrm{~b}$ & $30.5 \mathrm{~b}$ & $3.86 \mathrm{~b}$ & 245 & 41.2 & $3113 b$ \\
\hline Fallow & $25.6 \mathrm{a}$ & 39.4 a & $5.48 a$ & 267 & 41.5 & 3812 a \\
\hline
\end{tabular}

(1) Days before soybean sowing (DBSS), (2) Desiccated (Des.), ${ }^{(3)}$ Means not followed by the same letter differ from each other by the Scott-Knott test at $5 \%$ probability of error, ${ }^{\text {ns }}$ Not significant.

\section{Conclusions}

The production of ryegrass hay in a lowland area is a viable alternative, however it reduces the potassium content in the soil if replacement fertilization is not carried out.

Ryegrass causes a reduction in the grain yield of soybeans grown in lowland areas in years of high rainfall during soybean sowing, regardless of the haymaking or desiccation season.

\section{Literature Cited}

Anjos, J.C.R.; Andrade Júnior, A.S.; Bastos, E.A.; Noleto, D.H.; Melo, F.B.; Brito, R.R. Water storage in a Plinthaqualf cultivated with sugarcane under straw levels. Pesquisa Agropecuária Brasileira, v.52, n.6, p.464-473, 2017. https://doi.org/10.1590/S0100204X2017000600010.

Assmann, J.M.; Braida, J.A.; Cassol, L.C.; Magiero, E.C.; Manteli, E.; Griz, E. Produção de matéria seca de forragem e acúmulo de nutrientes em pastagem anual de inverno tratada com esterco líquido de suínos. Ciência Rural, v.39, n.8, p.2408-2416, 2009. https://doi.org/10.1590/S010384782009000800021 .
Cavalcante, M.A.B.; Pereira, O.G.; Filho, S.C.V.; Ribeiro, K.G.; Pacheco, L.B.B.; Araújo, D.; Lemos, V.M.C. Níveis de proteína bruta em dietas para bovinos de corte: parâmetros ruminais, balanço de compostos nitrogenados e produção de proteína microbiana. Revista Brasileira de Zootecnia, v.35, n.1, p.203-210, 2006. https://doi.org/10.1590/S151635982006000100026.

Cruz, S.C.S.; Sena-Júnior, D.G.; Santos, D.M.A.; Lunezzo, L.O.; Machado, C.G. Cultivo de soja sob diferentes densidades de semeadura e arranjos espaciais. Revista de Agricultura Neotropical, v.3, n.1, p.1-6, 2016. https://doi.org/10.32404/ rean.v3i1.431.

Difante, G.S.; Marchesan, E.; Villa, S.C.C.; Rocha, Santos, F.M.; Camargo, E.R. Produção de novilhos de corte com suplementação em pastagem de azevém submetida a doses de nitrogênio. Revista Brasileira de Zootecnia, v.35, n.3, p.1107-1113, 2006. https://doi.org/10.1590/S1516-35982006000400023.

Empresa Brasileira de Pesquisa Agropecuária - Embrapa. Sistema brasileiro de classificação de solos. 3.ed. Brasília: Embrapa Solos, 2013. 353p.

Fehr, W.R.; Caviness, C.E. Stages of soybean development. Ames: State University of Science and Technology, 1977. 11 p. (Special report, 80). 
Ferreira, R.B.; Marchesan, E.; Coelho, L.L.; Oliveira, M.L.; Telo, G.M.; Cargnelutti-Filho, A.; Sartori, G.M.S. Manejo do azevém no estabelecimento inicial de plantas, na ciclagem de nutrientes e no rendimento de grãos do arroz irrigado. Ciência Rural, v.45, n.12, p.2143-2149, 2015. https://doi.org/10.1590/0103$8478 \mathrm{cr} 20131473$.

Ribeiro Filho, H.M.N.; Semmelemann, C.E.N.; Heydt, M.S.; Neto, A.T. Suplementação energética para vacas leiteiras pastejando azevém com alta oferta de forragem. Revista Brasileira de Zootecnia, v.36, n.6, p.2152-2158, 2007. https://doi.org/10.1590/S151635982007000900027.

Fin, S.S.; Marchesan. E.; Gubiani, P.I.; Farenzena, J.A.; Murari, M.S.; Coelho, L.L.; Cargnelutti Filho, A.; Aramburu, B.B. Duration of the effects of scarification and raised bed associated with vegetation cover on soybean yield on an Alfisol. Pesquisa Agropecuária Brasileira, v.53, n.12, p.1231-1239, 2018. https:// doi.org/10.1590/s0100-204×2018001100005.

Giacomeli, R.; Marchesan, E.; Donato, G.; Silva, P.R.F.; Kaiser, D.R.; Aramburu, B.B. Escarificação do solo e sulcadores em semeadora para cultivo de milho em Planossolos. Pesquisa Agropecuária Brasileira, v.51, n.3, p.261-270, 2016. http://doi.org/10.1590/ S0100-204X2016000300008.

Grable A.R.; Danielson, R.E. Effect of carbon dioxide, oxygen, and soil moisture suction on germination of corn and soybeans. Soil Science Society, v.29, n.1, p.12-18, 1965. https://doi. org/10.2136/sssaj1965.03615995002900010007x.

Li, S.; Li, Y.; Lin, H.; Feng, H.; Dyck, M. Effects of different mulching technologies on evapotranspiration and summer maize growth. Agricultural Water Management. v.201, p. 309-318, 2018. https://doi.org/10.1016/j.agwat.2017.10.025.

Modolo, A.J.; Trogrelllo, E.; Nunes, A.L.; Silveira, J.C.M.; Kolling, E.M. Efeito da compactação do solo sobre a semente no desenvolvimento da cultura do feijão. Acta Scientiarum. Agronomy, v.33, n.1, p.89-95, 2011. https://doi.org/10.4025/ actasciagron.v33i1.4236.

Moreno, J.A. Clima do Rio Grande do Sul. Porto Alegre: Secretaria de Agricultura, 1961. 41p.

National Research Council - NRC. Nutrient requirements of beef cattle. 6.ed. Washington: National Academy Press, 1984. 63p. https://doi.org/10.17226/19398.

Nobrega, L.H.P.; Lima, G.P.; Martins, G.I.; Meneghetti, A.M. Germinação de sementes e crescimento de plântulas de soja (Glycine max L. Merrill) sob cobertura vegetal. Acta Scientiarum, Agronomy, v.31, n.3, p.461-465, 2009. https://doi.org/10.4025/ actasciagron.v31i3.320.

Pellegrine, L.G.; Monteiros, A.L.G.; Neumann, M.; Moraes, A.; Pellegrin, A.C.R.S.; Lustosa, S.B.C. Produção e qualidade de azevém-anual submetido a adubação nitrogenada sob pastejo por cordeiros. Revista Brasileira de Zootecnia, v.39, n.9, p.1894-1904, 2010. https://doi.org/10.1590/S1516-35982010000900006.
Redin, M.; Recous, S.; Aita, C.; Dietrich, G.; Skolaude, A.C.; Ludke, W.H.; Schmatz, R.; Giacomini, S.J. How the chemical composition and heterogeneity of crop residue mixtures decomposing at the soil surface affects $\mathrm{C}$ and $\mathrm{N}$ mineralization. Soil Biology \& Biochemistry, v.78, p.65-75, 2014. https://doi.org/10.1016/j.soilbio.2014.07.014.

Reis, D.A.; Lima, C.L.R.; Bamberg, A.L. Physical quality and organic matter fractions of an Alfisol under no-tillage. Pesquisa Agropecuária Brasileira, v.51, n.9, p.1623-1632, 2016. https:// doi.org/10.1590/S0100-204X2016000900062.

Rosin, D.C.; Maria, I.C.; Silva, R.L.; Silva, A.P. Compactação de um Latossolo Vermelho Distroférrico com diferentes quantidades e manejos de palha em superfície. Bragantia, v.71, n.4, p.502-508, 2014. https://doi.org/10.1590/S0006-87052013005000003.

Silva, A.A.; Silva, P.R.F.; Suhre, E.; Argenta, G.; Streider, M.L.; Rambo, L. Sistemas de coberturas de solo no inverno e seus efeitos sobre o rendimento de grãos do milho em sucessão. Ciência Rural, v.37, n.4, p.928-935, 2007. https://doi.org/10.1590/S010384782007000400002 .

Silva, M.S.; Pelissari, A.; Moraes, A.; Sandini, I.E.; Cassol, L.C.; Assmann, T.S.; Oliveira, E.B. Acumulação de nutrientes e produção forrageira de aveia e azevém em função da aplicação de calcário e gesso em superfície. Revista de Ciências Agrárias, 2015, v.38, n.3, p. 346-356. https://doi.org/10.150/S0101-312280001007.

Singh, Y.; Sidhu, H.S. Management of cereal crop residues for sustainable rice-wheat production system in the Indo-Gangetic plains of India. Proceedings of the Indian National Science Academy, v.80, n.1, p.95-114, 2014. http://doi.org/10.16943/ ptinsa/2014/v80i1/55089.

Tilley, J.M.A.; Terry, R.A. A two stage technique for the in vitro digestion of forage crops. Journal of the British Grassland Society, v.18, n.2, p.104-111, 1963. https://doi.org/10.1111/j.1365-2494.1963. tb00335.x.

Van-Soest, P.J.; Robertson, J.B.; Lewis, B.A. Methods for dietary fiber, neutral detergent fiber, and nonstarch polysaccharides in relation to animal nutrition. Journal of Dairy Science, v.74, n.10, p.35833597, 1991. https://doi.org/10.3168/jds.S0022-0302(91)78551-2.

Wells, M.S.; Smith, A.N.; Grossman, J.M. The reduction of plantavailable nitrogen by cover crop mulches and subsequent effects on soybean performance and weed interference. Agronomy Journal, v.105, n.2, p.539-545, 2013. http://doi.org/10.2134/ agronj2012.0396.

Wu, C.; Chen, P.; Hummer, W.; Zeng, A.; Klepadlo, M. Effect of flood stress on soybean seed germination in the field. American Journal of Plant Sciences, v.8, n.1, p.53-68, 2017. https://doi. org/10.4236/ajps.2017.81005.

Ziech, A.R.D.; Conceição, P.C.; Luchese, A.V.; Balin, N.M.; Candiotto, G.; Garmus, T.G. Proteção do solo por plantas de cobertura de ciclo hibernal na região Sul do Brasil. Pesquisa Agropecuária Brasileira, v.50, n.5, p.374-382, 2015. https://doi.org/10.1590/ S0100-204X2015000500004. 